\title{
Agnieszka Strzałka
}

Uniwersytet Pedagogiczny im. Komis̈i Edukacï Narodowej,

Krakón

\section{STRATEGIE INTERAKCYJNE LEKTORÓW, Z KTÓRYMI DOROŚLI CHCĄ PRACOWAĆ}

\begin{abstract}
Knowing that there is a definite link between instructor - student interaction and students' affect, as there is between affect and learning, the article provides a look at the ways in which FL teachers address adult learners. Teaching adult learners in general constitutes a challenge since the group are especially sensitive to self image and easily get demotivated. Teacher's behaviour, her attitude to the adult student and the atmosphere of learning are among the most important motivational factors for adults. The article is an attempt at presenting specific interactional strategies good teachers practice in order to motivate adults, offer them a sense of security and satisfy their face needs.
\end{abstract}

\section{Wprowadzenie}

Na wstępie należy zaznaczyć, iż w rzeczywistości grupa szkolonych dorosłych dzieli się na szereg tzw. grup docelowych, których specyficzne potrzeby i biografia edukacyjna, w tym doświadczenie w nauce języka obcego, będą różnić się od pozostałych. W swojej praktyce nauczycielskiej zetknęłam się, między innymi, z grupami zupełnie początkujących pracowników sektora bankowego w starszym wieku, jak i średnio- i zaawansowanymi grupami młodszych pracowników tegoż sektora obu płci. Prowadziłam zajęcia z początkującymi sekretarkami na kursach doskonalenia zawodowego i pracownikami linii produkcyjnej w fabryce słodyczy, którzy nigdy wcześniej nie uczyli się żadnego języka zachodniego. Zdarzali się początkujący, średnio-, jak i zaawansowani członkowie wyższej kadry zarządzającej sektora bankowego i administracji publicznej, często, lecz nie zawsze, władający innym językiem (w przeważającej mierze mężczyźni). Obok młodych pracowników firm informatycznych po studiach (bardzo niewielki odsetek pań) 
na rożnym poziomie zaawansowania, pojawiło się kilka osób z podstawowym lub średnim wykształceniem, planujących wyjazd zagranicę w celu podjęcia pracy fizycznej. Ich wspólną cechą było to, że musieli widzieć, ze ich nauka w wieku dorosłym ma sens, a nauczyciel z którym pracują szanuje ich niezależność, mimo iż w nauce języka obcego często czuli się jak „,dzieci we mgle”.

\section{Praca z dorosłymi wyzwaniem dla lektorów języka obcego}

Jak czytamy w dokumencie europejskim: „Nauczyciele języków często muszą walczyć z brakiem pewności siebie u swoich uczniów wynikającym z niedostatków edukacji językowej w przeszłości. Muszą pokonać również stereotyp wygłaszany przez uczniów pozbawionych w przeszłości możliwości uczenia się języka, że nauka języków jest trudna i „nie dla mnie”. Budowanie pewności siebie u uczniów i podtrzymywanie ich motywacji to główne wyzwania dla nauczycieli uczacych dorosłych ludzi” (http://ec.europa.eu/education/languages).

Fragment ten uzmysławia nam wagę strategii nauczycielskich, które mają wpływ na element afektywny procesu uczenia się, a więc to jak uczący się postrzega własne szanse na odniesienie sukcesu, jak ocenia swoje możliwości (zdolności) opanowania języka obcego, jak silna jest jego motywacja do podjęcia i kontynuowania nauki, mimo wielu innych obowiązków zawodowych i rodzinnych, oraz jak duży niepokój odczuwa w związku z sytuacją uczenia się. Niepokój związany z postrzeganą trudnością materiału, osobą nauczyciela, innymi osobami w grupie, a dokładnie ich ocena jego kompetencji oraz obrazem samego siebie.

\section{Afekt w nauczaniu dorosłych}

Afekt, rozumiany jako emocjonalna reakcja na język, którego naukę podejmuje się, środowisko uczenia (m.in. inne osoby), jak też własną osobę w procesie uczenia się odgrywa ważną rolę w nauczaniu wszystkich grup wiekowych.

Podczas gdy pozytywne emocje prowadzą do wzmożenia wysiłków i podtrzymywania decyzji o uczeniu się, negatywne odczucia, takie jak lęk, znudzenie, czy brak satysfakcji, prowadzą zwykle do gorszych efektów nauczania. Emocje szczególnie dają się we znaki w przypadku dorosłych, gdyż ci, jako samostanowiący o swojej dalszej nauce, mają możliwość rezygnacji z niej. Powodów zaprzestania nauki doszukiwać można się właśnie w sferze emocjonalnego nastawienia do uczenia się języka obcego.

\subsection{Motywacja u dorosłych}

Bye, Pushkar i Conway (2007) stwierdzają, że „nietradycyjni” studenci, a więc ci uczący się poza wiekiem normalnie przeznaczonym na edukację wykazują wyższy stopień motywacji wewnętrznej. W świetle ich badań dorośli charakteryzuja się większą wewnętrzną potrzebą uczenia się niż osoby młodsze. Czy stwierdzenie to jest prawdziwe również w odniesieniu do nauki języka obcego? Poza for- 
malnym systemem nauczania nauka nie jest już obowiązkowa (tak jak na nieobowiązkowych studiach wyższych lektorat języka obcego wciąż jest obowiązkowy), a więc wybrali swoje kursy lub studia dobrowolnie. W obecnej sytuacji, znajomość języka obcego często decyduje o zatrudnieniu, zwolnieniu lub wysokości osiaganej pensji. Możemy więc o motywacji dorosłych powiedzieć, że jest, niejednokrotnie silna, motywacją instrumentalna, która powinna dawać dobre rezultaty nauki. Z drugiej strony, ,silniejszym [niż nagrody zewnętrzne] czynnikiem motywacyjnym jest zaspokojenie potrzeb wewnętrznych" (Knowles, Holton i Swanson, 2009: 182), takich jak potrzeba aktywności i potrzeba rozwoju. W praktyce okazuje się jednak, że motywacja dorosłych, często słabnie, prowadząc do częstych rezygnacji z nieobowiązkowej w końcu nauki, a jedną z ról instruktora staje się właśnie podtrzymywanie tej motywacji.

\subsection{Obraz samego siebie (self-esteem)}

$\mathrm{Na}$ utrzymanie motywacji do uczenia się języka obcego nieodwołalnie ma wpływ obraz samego siebie, jaki tworzy się u osoby dorosłej w związku z sytuacja, uczenia się. Jeśli zagrożone zostana potrzeby bezpieczeństwa, własnej tożsamości jako osoby dorosłej, kierującej samym soba, czy przynależności do grupy, rozumianej tu jako poczucie bycia na zbliżonym poziomie i dzielenia celów uczenia się z innymi oraz dokonywania porównywalnych postępów, motywacja może spaść poniżej poziomu niezbędnego do kontynuacji nauki (por. de Andres, 1999 za Reasoner).

\subsection{Poziom lęku}

Wysoki poziom lęku skorelowany jest w nauce języka obcego z niskimi wynikami, gorszym radzeniem sobie z zadaniami na mówienie i pisanie, mała pewnością siebie oraz niską samoocena (Oxford, 1999: 61). Jednak, związek poziomu leku z osiaganymi wynikami uczenia się nie jest prosty, a niektórzy badacze twierdza, że lek spowodowany jest problemami w nauce, a nie odwrotnie (ibid.). Osoby, u których poziom leku jest wyższy od innych często „zacinają się”, zachowują nerwowo w czasie zajęć, doświadczaja problemów z wymową dźwięków języka obcego. Objawy mogą obejmować też tzw. zachowania maskujące nieustanny uśmiech, potakiwanie, żartowanie czy samokrytykę (ibid.: 66).

Udokumentowano związek pomiędzy poziomem lęku u uczących się a interakcją lektor/nauczyciel - uczeń. Najbardziej miażdżący wpływ na poziom lęku uczącego się wywrzeć może brak łagodnej poprawy, ośmieszanie i nietaktowna reakcja na błędy w obecności innych uczestników.

\subsection{Afekt $u$ dorosłych a zachowanie nauczyciela}

Wśród podstawowych warunków motywowania uczniów, Dörneyi (2001) wymienia odpowiednie zachowanie nauczyciela, dobre relacje z uczniami, miła i bezpieczną 
atmosferę oraz spójność grupy. W niniejszym badaniu przedmiotem szczególnej uwagi sa zachowania werbalne i niewerbalne lektora. Warto podkreślić, że zarówno w codziennych rozmowach, jaki w interakcjach profesjonalnych ogólne wrażenie stron nie jest tylko kwestią makro zachowań uznawanych za grzeczne, takich jak formy powitania, zwracania się do siebie, lub brak zachowań ogólnie uznanych za niegrzeczne (agresywne, nietaktowne zwroty), ale w dużej mierze kwestią niuansów doboru słów, tonu wypowiedzi i towarzyszących jej sygnałów para- i pozawerbalnych. To one tworzą miłą i bezpieczną dla dorosłego uczestnika atmosferę uczenia się.

\section{Badanie: obserwacja zachowań interakcyjnych lektorów pracujących z dorosłymi}

Dokonując zestawienia modelu technologicznego (nastawionego na nauczyciela), humanistycznego (nastawionego na ucznia) i krytycznego (nastawionego na refleksję) edukacji dorosłych, Pierścieniak (2005) wskazuje na model krytyczny, jako najbardziej dojrzały. Nauczyciel dorosłych staje się, w myśl tego modelu, krytycznym analitykiem indywidualnych sposobów życia i kompetentnym znawcą ludzkich osobowości. Będzie empatycznym przyjacielem, intelektualnym prowokatorem, skutecznym doradca, spolegliwym opiekunem itp. (ibid.: 25).

Wewnątrz tego modelu odnajdujemy m.in. zasadę uwzględniania roli emocji w procesie nauczania oraz zasadę wykorzystania humoru. Są dwie zasady, które wydały mi się szczególnie znajome z własnej praktyki nauczania dorosłych. Nie umniejszając żadnej z pozostałych zasad (takich jak zasada nacelowania na potrzeby uczestników czy wykorzystania ich uprzedniego doświadczenia), z których każda stanowi ważny element pracy z dorosłymi, i mogłaby być przedmiotem osobnych badań, chciałabym bliżej przyjrzeć się właśnie tym dwóm zasadom. W glottodydaktyce ogólnej coraz częściej mówimy o roli emocji, wykorzystanie humoru w nauczaniu języków obcych, jako węższe pole badawcze, również rozwija się w ostatnim czasie (por. Askildson, 2005; Wowro, 2009).

Pytanie które zadałam sobie dla niniejszego badania to: czy lektorzy, uznawani przez samych zainteresowanych - dorosłych uczących się języka angielskiego, za najlepszych, rzeczywiście te zasady stosują? W jakim stopniu są one obserwowalne oraz jak realizowane są w praktyce poprzez strategie interakcyjne, które nazwalam odpowiednio: strategiami wsparcia emocjonalnego i strategiami humoru?

Obserwacja dobrych nauczycieli przy pracy z dorosłymi wydała mi się dobrym narzędziem zebrania szczegółowych danych, które w przyszłości mogłyby posłużyć szkoleniu nauczycieli. Jak wiemy, niewielka część naszego kształcenia zawodowego nauczycieli języków obcych ma charakter przygotowania do pracy z konkretną grupą wiekowa. Jeśli programy instytucji kształcących nauczycieli filologów uwzględniają taką możliwość, dużo większą szansę mają studenci na zapoznanie się ze specyfiką pracy z najmłodszymi - grupą znajdującą się dziś w centrum uwagi, oraz stosukowo dobrze rozpoznana. Praktyka studencka pomaga również przyszłym nauczycielom zapoznać się głownie z pracą wśród dzieci i młodzieży. 
W czasie 18 godzin obserwacji 4 lektorów (dwóch kobiet i dwóch mężczyzn) konsekwentnie uznanych przez uczestników kursów języka angielskiego dla firm za bardzo dobrych, (okresowa ocena lektora) zanotowałam ok. 200 krótkich wymian interakcyjnych pomiędzy lektorem a uczestnikami. Uczestnikami kursów języka angielskiego dla firm były osoby w wieku od 20 do 50 lat, z wykształceniem wyższym na poziomach od początkującego do zaawansowanego (Cambridge Proficiency). Bardzo ważne było, aby transkrypcja zebranych danych odzwierciedlała subtelne cechy tych interakcji, takie jak znaczace pauzy, nakładanie się wypowiedzi, śmiech, a nawet jego rodzaj, przerwane wypowiedzi, emfaza, przedłużone dźwięki, parafraza rozumiana jako naśladowanie czyjegoś głosu (Rapley, 2010 za Poland, 2002). W praktyce okazało się, ze odnotowanie tych szczegółów jest możliwe jedynie przy bacznej obserwacji wszystkiego co się dzieje w sali, dlatego świadomie zrezygnowałam z nagrywania rozmów, zwłas zcza ze stwarzałoby to niekomfortową sytuację dla obserwowanych. Nawet jeśli jakaś część wymian uszła mojej uwadze, z powodu notowania na bieżąco, uznalam tę metodę za bardziej rzetelną dla badania o charakterze jakościowym.

\section{Analiza danych: interakcyjne strategie motywacyjne stosowane przez dobrych lektorów}

\begin{tabular}{|l|l|l|}
\hline Kategoria & Strategia & Przykłady* \\
\hline Interlanguage & Lagodna poprawa & {$[2][3]$} \\
\hline & Pozytywny feedback & {$[7]$} \\
\hline & Alternatywne ,nie” & {$[4][5][6]$} \\
\hline & Podpowiedź (szeptem/gestem) & {$[12][13]$} \\
\hline & Pytanie pomocnicze & {$[8]$} \\
\hline & Zachęta do samopoprawy & {$[9][10]$} \\
\hline & Podkreślenie & {$[11]$} \\
\hline & Aprobata/pochwała & {$[23]$} \\
\hline Problemy uczestnika & Zapewnienie & {$[1]$} \\
\hline & Zainteresowanie/Empatia & {$[14][15][16][17][18]$} \\
\hline & Pomoc/Wskazanie drogi & {$[19][20]$} \\
\hline & Zachęta do skorzystania z pomocy & {$[28]$} \\
\hline & Cierpliwe tłumaczenie & {$[22]$} \\
\hline & Cierpliwe oczekiwanie & {$[34]$} \\
\hline Relacje & Zwracanie się po imieniu & {$[21]$} \\
\hline & Dbałość o uczestnika & {$[25][26][27]$} \\
\hline & Rutynowa grzeczność & {$[29][30][31][32]$} \\
\hline & Grzeczne zakończenie tematu & {$[33]$} \\
\hline & Small talk & {$[40][41][42]$} \\
\hline & Unikanie imperatywu & {$[35][36]$} \\
\hline & Równe traktowanie & {$[38][39]$} \\
\hline & Dygresja - nawiązanie do „,real life” & {$[37][38]$} \\
\hline & Reagowanie emocjami & {$[39]$} \\
\hline & & \\
\hline & &
\end{tabular}

Tabela 1: Strategie wsparcia emocjonalnego. * pełne przykłady dostępne w załączniku. 


\subsection{Lagodna poprawa, pozytywny feedback, pomoc}

Podkreśla się sukces interakcyjny nauczycieli, którzy „,zęstym chwaleniem, słowem, jak i w sposób niewerbalny zapewniają, wmyśl założeń metody naturalnej, niski filtr afektywny, ułatwiający zapamiętywanie i uczenie się" (Komorowska, 2007: 114). Ważny dla motywacji i pozytywnego afektu dobry sposób dostarczania informacji zwrotnej (por Nunan, 1991 cyt. przez Zhao, 2010) przejawia się u obserwowanych lektorów w następujących formach: jako reakcja na błąd, forma poprawna podawana jest $z$ naciskiem lecz tonem łagodnym, bez irytacji (przykład[2]). Innym razem [3] bez nacisku, jakby nigdy nic. Ton podkreślenia [9] jest rzeczowy, nie wprowadza elementu krytyki. Nie pojawia się kategoryczne: „nie, to nie jest poprawna odpowiedź”, zdarza się zabawna infantylizacja „nie” (m.m) lub taktowne „tak, ale”, zamiast nie. Sposób artykulacji świadczy o kreatywności lektorów w tym względzie (np. kilkakrotne, szybkie nie brzmi łagodniej niż jedno NIE). Często potwierdzana jest poprawność, w trakcie lub po wypowiedzi. Pytania pomocnicze redukują długość krepującego milczenia po stronie ucznia [8]. Może to być np. podanie dwóch możliwości do wyboru. Pytania dające wybór ułatwiaja znalezienie właściwego słowa [9].

Pozytywny feedback jest ogólnie częsty, sporadycznie zaś podkreślony głosem [11]. Ponieważ częsta ale rutynowa pochwala [7] może brzmieć mechanicznie (por. Brophy, 1981; Nunan, 1991 cyt. przez Zhao, 2010), od czasu do czasu lektorzy stosują wyraźne, mało powtarzalne formy aprobaty [23][24].

\subsection{Zrozumieć dorosłego}

Lektor nie pozostawia uczestnika samego z jego problemami[19]. Lektor zwraca uwage nie tylko na "problemy” językowe[14]. W momentach gdy uczestnicy dostrzegają (a może wyolbrzymiają?) swoje trudności, lektor wykazuje empatię. Lektorzy wyczuleni są na parawerbalne sygnały ze strony uczestników - kiedy na przykład intonacja uczestniczki pokazuje, że nie rozumie ona typu zdania, lektor „spieszy” z pomoca [19]. W przykładzie [28] uczestniczki są jakby zawstydzone, że nie pamiętaja potrzebnych zwrotów, lektor rozwiewa to uczucie, podsuwając rozwiązanie problemu (nie gotową odpowiedź). W [20] ton głosu lektora mówi jakby „nie wiedziałeś, ale już wiesz i to dzięki sobie.” Zaobserwowane strategie zdają się być trafną odpowiedzią na potrzeby dorosłych uczących się związane z zachowaniem twarzy w sytuacji „raczkowania” w języku obcym.

\subsection{Rożne formy grzeczności, partnerstwo, takt}

Zachowania grzecznościowe należą do strategii wsparcia emocjonalnego, gdyż relaksują uczestników. „Eksperci pozdrawiają uczestników na samym wstępie zajęć, nie śpieszą się z wprowadzaniem tematu i dbają o utrzymanie miłej atmosfery" (Knowles, Holton i Swanson, 2009: 276). 
Zwracając się po polsku lektorzy używają formy pani + imię, lub imię [21]. Po angielsku - imię. Zdarzają się zdrobnienia. Uczestnicy mogą liczyć na dbałość lektora o ich „bycie na bieżąco”, często zaniedbywane powodu innych obowiązków. W [25] lektor wie, że luźne materiały mogą się zagubić, jest gotowy dać nowa kopię. Spóźniony uczestnik [26]dostaje materiały i informacje, co aktualnie się dzieje.

Grzeczne zwroty pojawiają się w rożnych momentach zajęć, przykładowo lektor kończy zajęcia rutynowym podziękowaniem, wyraża zdziwienie w grzeczny sposób, a nawet, zadając do domu formułuje polecenia jako grzeczna prośbę. Zamiast „now open your books...” słyszymy, „next exercise on page...”. W [33] nie pesząc mówiącego lektor sygnalizuje, że czas przejść dalej.

Rutynowe (tj. oparte na istniejących w języku docelowym formułach grzecznościowych) zachowania interakcyjne zostały zaobserwowane w momencie rozpoczynania i kończenia zajęć [29], jak również przy przechodzeniu od jednego zadania do drugiego, zadawaniu pracy domowej [31] i przy wymianie zdań będącej częścia „,speaking practice” [30]. W [40][41]lektor niespiesznie rozpoczyna zajęcia, poświęcając czas na rozmowy wstępne (phatic communion). W [37] słówko w ćwiczeniu staje się okazją do porozmawiania, w tym wypadku o sztukach teatralnych, jakie można zobaczyć w mieście. Podkreślana jest równość, partnerstwo obu stron - nauczyciel uczy się/dowiaduje czegoś od dorosłego uczestnika, sa partnerami w rozmowie. Stawiane pytania nie sa tylko pytaniami nauczycielskimi[38]. Reakcja nie jest tylko uznaniem poprawności wypowiedzi, ale odnosi się do jej treści [39].

Zachowania interakcyjne wobec innych grup uczących się prawdopodobnie różnią się znacznie. Pewne formy grzecznościowe byłyby uznane za dziwne w stosunku do dzieci czy nastolatków. W gimnazjum nauczyciel może przekazać komunikat „pora przejść dalej” bardziej otwarcie: „Sorry, man, your time is up”. Z drugiej jednak strony, brak obecności form grzecznościowych w dyskursie nauczycieli w tradycyjnym nauczaniu stanowi brak odpowiedniego modelu dla uczniów w ich komunikacji poza klasą.

\begin{tabular}{|l|l|l|}
\hline Kategoria & Strategia & Przykład \\
\hline Poprawa błędów & Przyjazny śmiech/Pytanie & {$[43]$} \\
\hline & „Niedowierzanie” & {$[44][45]$} \\
\hline & Akceptacja „kreatywności” & {$[52]$} \\
\hline Problemy uczestników & „Śmiech na utyskiwanie” & {$[46][55]$} \\
\hline & Uznanie dla dystansu do samych siebie - śmiech & {$[48][49]$} \\
\hline & Zwrócenie uwagi poprzez humor & {$[53]$} \\
\hline Humor interakcji właściwej & Ironia & {$[50]$} \\
\hline & Zabawne gesty & {$[51]$} \\
\hline & „Obrona przed oczekiwaniami” & {$[54]$} \\
\hline & Humor elicytacji & {$[56][57]$} \\
\hline & Komentarz do słów uczestnika & {$[58][59][60]$} \\
\hline Urozmaicenie zajęć & Konwencja zabawy & {$[47]$} \\
\hline & Zabawne elementy języka & {$[61]$} \\
\hline & Zabawne historyjki z życia & {$[62]$} \\
\hline
\end{tabular}

Tabela 2: Strategie humoru. 


\subsection{Poprawiać nie raniąc}

Unikanie przez lektora bezpośredniości, poprzez zastosowanie sugestii czy pytań retorycznych to cechy tzw. grzeczności typu off-record. (Jiang, 2010 za Brown i Levinson, 1987). W omawianych przykładach z grupy strategii zastosowania humoru dodatkowo pojawia się uśmiech czy nawet śmiech, pozbawiony elementu drwiny [43]. Nauczyciel okazuje zrozumienie poprzez humor, jakby mówił: „pomyłki się zdarzaja. Te wyrazy brzmia podobnie, ale znaczą co innego”. Jednak w tonie wypowiedzi brak jest sarkazmu [44][45]. Lektor zadaje pytanie zamiast stwierdzać „it’s not polite” [43]. W przykładzie [52] w powtórzeniu słów uczestniczki przez lektora nie ma sarkazmu. Akceptuje jej połowiczne rozwiązanie i zachęca do dalszego „szukania w pamięci”.

\subsection{W co grają uczestnicy?}

Mniej lub bardziej świadome maskowanie lęku skłania czasem dorosłych do (żartobliwego) narzekania, utyskiwania i samokrytyki. W [48] lektor podchwytuje żartobliwy ton uczestniczki, doceniając jej dystans. Innym razem lektorka kwituje serie utyskiwań na gramatykę [46] po prostu śmiechem. W [53] lektor wykorzystuje sytuację, w której uczący się sam stwierdza, że nie idzie mu zbyt dobrze, aby przypomnieć mu, że systematyczność jednak pomaga.

\subsection{Być zabawnym z umiarem}

Warto tu przypomnieć, że zaleca się ostrożne użycie humoru w klasie i innych kontekstach publicznych (Schmitz, 2002 za Deneire, 1995): „Zdrowy rozsadek i takt $\mathrm{z}$ pewnością będą dobrym przewodnikiem dla nauczyciela $\mathrm{w}$ doborze odpowiedniego typu humoru dla konkretnej sytuacji w klasie" (ibid.: 3). U wszystkich z badanych lektorów zaobserwowałam strategię „zabawnych gestów”, która jednak nie jest nadużywana. Żaden z lektorów nie przyjmuje roli komika. W [54] sama sytuacja, czy może słuchany tekst jest lekko humorystyczny. Byłoby weselej gdyby lektor zademonstrował śpiewanie, jednak nie decyduje się na tę rolę. Efekt jest równie humorystyczny. Lektor przejawia poczucie humoru również w obrębie roli elicytatora [56][57]. Zachęca do odpowiedzi na „prywatne” pytanie, obracając to w żart. Wie na jakie tematy można żartować z dorosłymi uczestnikami, w zależności od składu grupy [58][59]. Zabawna interakcja, stosowana z umiarem wprowadza atmosferę humoru i rozluźnienia.

\subsection{Unikanie nudy}

Ostatnia kategoria zachowań humorystycznych wydaje się spełniać rolę przerywników, dobrze wplecionych w strukturę lekcji. Lektor bawi uczestników i 
samego siebie, okraszając zajęcia zabawnymi elementami języka [61], przytaczając zabawne historyjki z życia [62].

\section{Zachowania interakcyjne lektorów: wnioski}

Analizując zachowania werbalne lektorów, nie sposób pominąć zachowania interakcyjnego samych dorosłych uczących się języka obcego. Wydaje się, ze dorośli w pełni świadomi trudności, jakie przychodzi im pokonać w nauce języka obcego, o których była mowa we wstępie. Można zaobserwować, że również dają wyraz przė̇ywanym trudnościom, na przykład komentując je otwarcie: „miałam przerwe”, „i znowu zapomniałam”, „źle zadałam pytanie” (bardziej charakterystyczne dla kobiet), lub żartując z całej sytuacji w języku polskim lub angielskim, na przykład w trakcie rozmów sterowanych, gier na role (,why do you want to sack us, because our English is bad"? (uczestnik w roli pracownika, do uczestnika w roli pracodawcy), częściej zaobserwowane u mężczyzn. Przyznanie się do trudności jest jednocześnie informacją dla lektora i może być traktowane jako prośba o pomoc. Jak widzieliśmy, lektorzy reaguja na te sygnały, okazując postawę pomocy, zrozumienia, kierując procesem nauczania w taki sposób, aby dorosły uczestnik miał jak najmniej okazji do poczucia zawstydzenia. Z pewnością uczucia takie niejednokrotnie towarzyszą dorosłym w ich nauce języka obcego. Należy jednak przyznać, ze dobry lektor zwraca czujną uwagę na swoje relacje z uczestnikami, na zachowanie swoistej równowagi, jakże niecharakterystycznej dla edukacji dzieci i młodzieży, gdzie nauczyciel zawsze pozostaje w pozycji auktorialnej w stosunku do ucznia.

Strategie wsparcia emocjonalnego, z jakimi spotkaliśmy się podczas badania wydaja się dobrze ilustrować ogólne zasady postępowania z dorosłymi na lekcji języka obcego. Zapewniono dobry klimat, budowano przyjazne, acz profesjonalne relacje, reagowano na zahamowania i wrażliwość na punkcie własnej niezależności jako osoby dorosłej.

Zaobserwowane strategie humoru, stosowane przez tę mała grupę dobrych lektorów, moga pomoc w refleksji nad rolą humoru w nauczaniu dorosłych. Spełnia on przynajmniej kilka funkcji - ogólna, do której zaliczyłabym wprowadzanie miłej, nieskrępowanej atmosfery oraz autoprezentację lektora jako osoby otwartej, przystępnej, oraz szereg funkcji szczegółowych. Funkcje te to: łagodna poprawa błędów, okazywanie empatii, upominanie, również realizowane właśnie poprzez humor. Wydaje się że, używając humoru lektorzy starają się obniżyć stres, jaki dorośli odczuwają w związku z nauką języka obcego.

\section{Podsumowanie}

Przedstawiony przeze mnie obraz dyskursu edukacyjnego w szkoleniu dorosłych jest z pewnością fragmentaryczny. Jak pisałam, dotyczy realizacji tylko dwóch wybranych zasad nauczania dorosłych oraz określonego kontekstu (szkolenia 
językowego w firmie). Wydaje się jednak, że przeanalizowany materiał ujawnia pewne istotne elementy repertuaru dobrej praktyki w zakresie nauczania dorosłych. Fakt, że niektóre strategie odnotowane zostały tylko raz w czasie całej obserwacji (np. „Obrona przed oczekiwaniami”) świadczyć może o idiosynkratycznym charakterze strategii, zwłaszcza tych z grupy użycia humoru, istnieje jednak szansa, że przy dłuższym badaniu większej liczby lektorów ten rodzaj zachowania pojawiłby się znowu. Trzeba również zaznaczyć, że w analizie użyłam własnej, wąskiej kategoryzacji rodzajów humoru, gdyby posłużyć się tylko kilkoma szerszymi kategoriami, w każdej znalazło by się więcej przykładów. Mam nadzieję, że przytoczone przykłady strategii wsparcia emocjonalnego i użycia humoru mogą być pomocne w kształceniu nauczycieli, jak również stanowić punkt wyjścia do dalszych badań nad edukacją językową dorosłych, w szczególności nad dyskursem edukacyjnym tej grupy wiekowej.

\section{BIBLIOGRAFIA}

Askildson, L. 2005. „Effects of humor in the language classroom. Humor as a tool in theory and Practice". Arizona Working Papers in SLAT - Vol. 12, pp 45-61. http://w3.coh.arizona.edu/. DW: 12.03.20011.

Bye, D., Pushkar, D. i Conway, M. 2007. „Motivation, Interest, and Positive Affect in Traditional and Nontraditional Undergraduate Students". Adult Education Quarterly, 57: 141-158.

De Andres, V. 1999. „Self-esteem in the classroom or the metamorphosis of butterflies." (w:) Affect in language learning. (red. J. Arnold). Cambridge: Cambridge University Press.

Dörnyei, Z. 2001. Teaching and Researching Motivation. England: Pearson Education Limited.

http://ec.europa.eu/education/languages/language-teaching/doc52_pl.htm.

Nauczanie języków obcych. Edukacja dorosłych. DW: 18.02.2011.

Jiang, X. 2010. „A Case Study of Teacher's Politeness in EFL Class”. Journal of Language Teaching and Research, 5, 651-655. http://ojs.academypublisher.com. DW: 1.03.2011.

Knowles, M. S., E. F. Holton III i R. A. Swanson. 2009. Edukacja dorostych. Wydawnictwo Naukowe PWN.

Komorowska, H. 2007. Metodyka nauczania jezyków obych. Warszawa: Fraszka Edukacyjna.

Oxford, R. L. 1999. „Anxiety and the language learner: new insights.” (w:) Affect in language learning. (red. J. Arnold). Cambridge: Cambridge University Press: 58-67

Pierścieniak, K. 2005. „Specyfika uczenia się dorosłych” (w:) Poradnik Edukatora (red. M. Owczarz). Warszawa: Wydawnictwo CODN: 17-28.

Rapley, T. 2010. Analiza konwersacji, dyskursu i dokumentów. Warszawa: Wydawnictwo Naukowe. 
Schmitz, J. R. 2002. „Humor as a pedagogical tool in foreign language and translation courses." Humor: International Journal of Humor Research, 15-1: 89-113.

Wowro, I. 2009. „Rola treści humorystycznych w nauczaniu języka obcego. Analiza wybranych podręczników do nauki języka niemieckiego." Neofilo$\log , 33: 269-282$.

Zhao, W. 2010. „An investigation of students' face wants in Chinese English teachers' Classroom Feedback". Journal of Language Teaching and Research, Vol. 1, No. 1: 29-34.

\section{Załącznik}

Tabela 1: Strategie wsparcia emocjonalnego.

\begin{tabular}{|c|c|c|c|}
\hline Kontekst & Strategia & Przykład & Wzór użycia \\
\hline Zakończenie zajęć & Zapewnienie & $\begin{array}{l}{[1]>\text { czy sa jakieś problemy }} \\
\text { Same problemy> } \\
>\text { dlatego poćwiczymy to } \\
\text { jeszcze }\end{array}$ & $\begin{array}{l}\mathrm{YM}>\mathrm{MF} \bullet \\
\mathrm{MF}>\mathrm{YM}\end{array}$ \\
\hline $\begin{array}{l}\text { Błąd gramatyczny } \\
\text { uczestniczki (forma } \\
\text { znana) }\end{array}$ & Lagodna poprawa & $\begin{array}{l}{[2] \text { I do not know what hap- }} \\
\text { pens to it> } \\
\text { > what HAS HAPPENED } \\
\text { What has happened }> \\
>\text { Yes, right } \\
{[3] \text { (...) not to worry her }} \\
\text { > not to worry, not to stress. } \\
\text { Not to stress. }\end{array}$ & $\begin{array}{l}\mathrm{YM}>\mathrm{MF} \\
\bullet \bullet \bullet \bullet \bullet \bullet \\
\mathrm{YF}>\mathrm{YMF} \\
\mathrm{MM}>\mathrm{MM}, \mathrm{YM} \\
\bullet \\
\mathrm{MF}>\mathrm{YM}\end{array}$ \\
\hline $\begin{array}{l}\text { Odpowiedź na pytanie, } \\
\text { próba nieuda- } \\
\text { na/niepełna }\end{array}$ & Alternatywne „nie” & $\begin{array}{l}{[4]>\text { m.m. (uśmiech) }} \\
{[5]>\text { ok., but let's look at it }} \\
\text { more globally. } \\
{[6]>\text { No, no no. }<}\end{array}$ & $\begin{array}{l}\mathrm{YF}>\mathrm{YF} \bullet \\
\mathrm{YM}>\mathrm{MF} \\
\mathrm{MM}>\mathrm{MM}, \mathrm{YM} \\
\bullet\end{array}$ \\
\hline Udana próba & Pozytywny feedback & [7]>mh. That's right. Yes. & $\begin{array}{l}\mathrm{YF}, \mathrm{MF}, \mathrm{YM}, \\
\mathrm{MM}>\text { > all } \\
\bullet \bullet \bullet \bullet \bullet \bullet \bullet\end{array}$ \\
\hline \begin{tabular}{|l|} 
Pytanie do przeczytane- \\
go tekstu, trudność w \\
udzieleniu odpowiedzi \\
Kłopoty z przypomnie- \\
niem właściwej formy \\
gramatycznej
\end{tabular} & Pytanie pomocnicze & $\begin{array}{l}{[8]>\text { Why was he at a wrong }} \\
\text { place at a wrong time?... } \\
\text { Where did he go? } \\
\text { To Bretany. } \\
>\text { How did he feel there? }\end{array}$ & $\begin{array}{l}\mathrm{YF}>\mathrm{YFF} \\
\mathrm{YM}>\mathrm{MF} \bullet\end{array}$ \\
\hline Niewłaściwe słowo & Zachęta do samopoprawy & $\begin{array}{l}9] \text { Fried }(. .) \\
>\text { Fried or ROAST? } \\
\text { Roast. } \\
{[10]>(\ldots .) \mathrm{Am}} \\
\text { AM? } \\
>\text { PM. } \\
\text { PM. } \\
\end{array}$ & \\
\hline \begin{tabular}{|l|}
$\begin{array}{l}\text { Dobra odpowiedź } \\
\text { (czasowniki nieregularne, } \\
\text { sprawiające trudność) }\end{array}$ \\
\end{tabular} & Podkreślenie & [11]>VERY good & $\mathrm{YF}>\mathrm{YFF}$ \\
\hline
\end{tabular}


Agnieszka Strzałka

\begin{tabular}{|c|c|c|c|}
\hline $\begin{array}{l}\text { Niepewność w trakcie } \\
\text { wypowiedzi }\end{array}$ & $\begin{array}{l}\text { Podpowiedź szeptem } \\
\text { Podpowiedź/Wskazówka } \\
\text { gestem }\end{array}$ & $\begin{array}{l}\text { [12]Although to wiec? } \\
\text { >chociaż. } \\
\text { [13]I znowu zapomniałam. } \\
\text { > starts with [d3]. }\end{array}$ & $\begin{array}{l}\mathrm{YF}>\mathrm{MF} \\
\mathrm{YM}>\mathrm{YF} \bullet \bullet\end{array}$ \\
\hline $\begin{array}{l}\text { Dużo nieznanych słó- } \\
\text { wek } \\
\text { Trudny fragment w } \\
\text { słuchance }\end{array}$ & Zainteresowanie/Empatia & $\begin{array}{l}{[14]>\text { What are you looking }} \\
\text { for? } \\
\text { Moment. (znajduje chusteczki i } \\
\text { wyciera nos) } \\
>\text { A! Everybody's ill. } \\
{[15]>\text { Any words you do not }} \\
\text { understand? } \\
\text { A lot of. } \\
>\text { A lot of! (uśmiech współczu- } \\
\text { cia) } \\
{[16] \text { it’s getting worse. }} \\
>\text { (uśmiech współczucia) } \\
{[17]>\text {...is fed up with gram- }} \\
\text { mar. } \\
{[18]>\text { That was a bit difficult }}\end{array}$ & $\begin{array}{l}\mathrm{YF}>\mathrm{MF} \bullet \bullet \bullet \\
\mathrm{YM}>\mathrm{MF} \\
\mathrm{MF}>\mathrm{YM} \\
\mathrm{MM}>\mathrm{MM} \bullet\end{array}$ \\
\hline $\begin{array}{l}\text { Kłopoty ze zrozumie- } \\
\text { niem fragmentu tekstu } \\
\text {...słowa. }\end{array}$ & Pomoc/wskazanie drogi & $\begin{array}{l}{[19], \text {,He does not look like }} \\
\text { [one?? > całe zdanie. He is a } \\
\text { millionaire but he does not } \\
\text { look like one. } \\
{[20] \text { COM -PE -TI -TIVE... }} \\
\text { nie wiem co to zna- } \\
\text { czy(zawstydzony?) } \\
\text { >Competitive. It's someone } \\
\text { who likes to compete to be } \\
\text { better. } \\
\text { Aha! Rywalizacja } \\
\text { >yes. Competition, and com- } \\
\text { petitive (....) }\end{array}$ & $\begin{array}{l}\mathrm{YF}>\mathrm{MF} \\
\mathrm{YM}>\mathrm{YM} \\
\bullet \bullet \bullet \bullet\end{array}$ \\
\hline Pytanie nauczyciela & Zwracanie się po imieniu & $\begin{array}{l}{[21]>* * * ?} \\
>\text { Pani } * * * ?\end{array}$ & $\begin{array}{l}\mathrm{YF}, \mathrm{YM}, \mathrm{MF}, \\
\mathrm{MM}>\text { all }\end{array}$ \\
\hline $\begin{array}{l}\text { Pytanie dot. gramatyki } \\
\text { słowa } \\
\text { Pytanie dot. czasu gra- } \\
\text { matycznego }\end{array}$ & Cierpliwe tłumaczenie & $\begin{array}{l}22] \text { shorts } \\
\text { Dlaczego to jest w liczbie } \\
\text { mnogiej? } \\
\text { >szorty. Tak jak po polsku. } \\
\text { Spodnie, szorty, w liczbie } \\
\text { mnogiej }\end{array}$ & $\begin{array}{l}\mathrm{YF}>\mathrm{MF} \\
\mathrm{YM}>\mathrm{MF} \bullet \bullet \bullet \\
\mathrm{MM}>\mathrm{MM}\end{array}$ \\
\hline $\begin{array}{l}\text { Zakończenie dłuższego } \\
\text { ćwiczenia/quizu } \\
\text { Rozmowa }\end{array}$ & Aprobata/pochwała & $\begin{array}{l}{[23]>\text { so, what's your score? }} \\
\text { Excellent. } \\
>\text { Congratulations. } \\
{[24]>\text { Good point. }}\end{array}$ & $\begin{array}{l}\mathrm{YM}>\mathrm{YF} \\
\mathrm{YF}>\mathrm{YMF} \\
\mathrm{MM}>\mathrm{MM}, \mathrm{YM} \\
\bullet \bullet\end{array}$ \\
\hline $\begin{array}{l}\text { Nawiazzanie do poprzed- } \\
\text { niej sesji }\end{array}$ & Dbałość o uczestnika & $\begin{array}{l}{[25]>\text { Last time I gave you a }} \\
\text { copy (pokazuje). Do you have } \\
\text { his copy? } \\
{[26]>\text { We are discussing this }} \\
\text { (przesyła kartę pracy) } \\
{[27]>\text { Were you here? I think }} \\
\text {...was the only person here. }\end{array}$ & $\begin{array}{l}\mathrm{YM}>\mathrm{MF} \\
\mathrm{MM}>\mathrm{MM} \\
\mathrm{MF}>\mathrm{YM}\end{array}$ \\
\hline
\end{tabular}


Strategie interakcyjne lektorów, z którymi dorośli chca pracować

\begin{tabular}{|c|c|c|c|}
\hline $\begin{array}{l}\text { Ćwiczenie wymagające } \\
\text { przywołania zwrotów z } \\
\text { poprzedniej/ich lekcji }\end{array}$ & $\begin{array}{l}\text { Zachęta do skorzystania z } \\
\text { pomocy }\end{array}$ & $\begin{array}{l}\text { [28]>można spróbować po- } \\
\text { szukać, jeśli się czegoś nie } \\
\text { pamięta, np. zwroty z look. }\end{array}$ & $\begin{array}{l}\mathrm{YM}>\mathrm{MF} \bullet \\
\mathrm{YF}>\mathrm{YMF}\end{array}$ \\
\hline Różny & Grzeczność & $\begin{array}{l}{[29]>\text { That's it for today. Thank }} \\
\text { you. } \\
{[30](\ldots) 20 \% \text {. }} \\
>\text { Really? Because I would think } \\
\text { it was } 90 . \\
{[31]>\text { If you could do that for }} \\
\text { homework.. because it take a } \\
\text { bit more time. } \\
{[32]>\text { Could I get your name }} \\
\text { here? }\end{array}$ & All $>$ all \\
\hline $\begin{array}{l}\text { Wypowiedz uczestnika } \\
\text { przedłuża się }\end{array}$ & $\begin{array}{l}\text { Grzeczne zakończenie } \\
\text { tematu. }\end{array}$ & [33]>Mh.Mh. All right. & $\mathrm{YF}>\mathrm{YMF}$ \\
\hline Brak odpowiedzi & Cierpliwe oczekiwanie & $\begin{array}{l}{[34]>\text { What is }() ?} \\
(4 s)\end{array}$ & $\mathrm{YM}>\mathrm{MF}$ \\
\hline Instruowanie & Zamiast imperatywu & $\begin{array}{l}{[35]>\text { more practice in the }} \\
\text { workbook. } \\
{[36]>\text { Let's try the next one. }}\end{array}$ & $\begin{array}{l}\mathrm{YM}>\mathrm{YF} \\
\mathrm{MM}>\mathrm{MM}, \mathrm{YM}\end{array}$ \\
\hline $\begin{array}{l}\text { Ćwiczenie na słownic- } \\
\text { two }\end{array}$ & $\begin{array}{l}\text { Dygresja - nawiązanie do } \\
\text { „real life” }\end{array}$ & $\begin{array}{l}\text { [37]> Have you seen „May- } \\
\text { day"? }\end{array}$ & $\begin{array}{l}\mathrm{MF}>\mathrm{MM}, \mathrm{MF} \\
\bullet \bullet\end{array}$ \\
\hline Czytanie/dyskusja & $\begin{array}{l}\text { Równe traktowanie } \\
\text { Reagowanie emocjami }\end{array}$ & $\begin{array}{l}{[38]>\text { Why could they want to }} \\
\text { export }(. . .) \text { ? } \\
\text { (uczestnik dostarcza wytluma- } \\
\text { czenia) } \\
>\text { oh, yes, that makes more } \\
\text { sense. } \\
{[39]>\text { Oh, my God. }}\end{array}$ & $\begin{array}{l}\mathrm{MM}>\mathrm{MM}, \mathrm{YM} \\
\bullet \bullet \bullet \bullet \\
\mathrm{MF}>\mathrm{YM} \bullet\end{array}$ \\
\hline Początek zajęć & Small talk & $\begin{array}{l}{[40]>\text { How are you? }} \\
{[41]>\text { Any plans for the week- }} \\
\text { end? Are you going to take } \\
\text { your wife anywhere? } \\
{[42]>\text { How is your dog? }}\end{array}$ & $\mathrm{MF}>\mathrm{YM}$ \\
\hline
\end{tabular}

Tabela 2: Strategie humoru.

\begin{tabular}{|c|c|c|c|}
\hline Kontekst & Strategia & Przykład & Wzór użycia \\
\hline $\begin{array}{l}\text { Odpowiedź niewłaściwa pod } \\
\text { względem pragmatyki języ- } \\
\text { kowej }\end{array}$ & $\begin{array}{l}\text { Przyjazny } \\
\text { śmiech/Pytanie reto- } \\
\text { ryczne }\end{array}$ & $\begin{array}{l}{[43]>\text { Someone invites you for }} \\
\text { dinner. How can you refuse } \\
\text { politely? } \\
\text { I am full }> \\
>\text { (śmieje sie). Is it polite? }\end{array}$ & $\begin{array}{l}\mathrm{YM}>\mathrm{MF} \bullet \\
\mathrm{MF}>\mathrm{YM}\end{array}$ \\
\hline $\begin{array}{l}\text { Niewłaściwy element leksy- } \\
\text { kalny }\end{array}$ & $\begin{array}{l}\text { Feedback typu „Nie- } \\
\text { dowierzanie” } \\
\text { Pytanie przyjaciel- } \\
\text { skie??? }\end{array}$ & $\begin{array}{l}{[44]>\text { How did He feel?> }} \\
\text { Incredibly. } \\
\text { >Incredibly? Niesamowicie? } \\
\text { (uśmiech)> } \\
\text { [Terribly. } \\
\text { > [yes. (śmiech). Terribly. } \\
\text { [45] (...) Koral war } \\
\text { >What war? (uśmiecha się) } \\
\text { Koral }\end{array}$ & $\mathrm{YF}>\mathrm{YF}$ \\
\hline
\end{tabular}


Agnieszka Strzałka

\begin{tabular}{|c|c|c|c|}
\hline & & $\begin{array}{l}\text { (gest o znaczeniu „,no, nie do- } \\
\text { kładnie)) } \\
\text { A! Wojny Krymskie } \\
\text { > Właśnie. (uśmiech) }\end{array}$ & \\
\hline $\begin{array}{l}\text { Narzekania na konieczność } \\
\text { powtarzania gramatyki } \\
\text { Westchnienie z ulga po } \\
\text { skończonym ćwiczeniu. }\end{array}$ & $\begin{array}{l}\text { „Śmiech na utyskiwa- } \\
\text { nie” }\end{array}$ & $\begin{array}{l}{[46] \text { > Które są regularne a które }} \\
\text { nie?> } \\
\text { Ach, gramatyka. ...nie możemy } \\
\text { się uczyć bez gramatyki? } \\
\text { >Zaraz będziemy opowiadać o } \\
\text { wakacjach w zeszłym roku. } \\
\text { S2: to w czasie przeszłym } \\
\text { > no właśnie } \\
\text { S1 (wzdycha) } \\
\text { > (Śmiech) }\end{array}$ & $\begin{array}{l}\mathrm{YF}>\mathrm{MF} \\
\mathrm{YM}>\mathrm{MF}\end{array}$ \\
\hline $\begin{array}{l}\text { Zadawanie pytań w czasie } \\
\text { przeszłym. Lektor rozdaje } \\
\text { obrazki }\end{array}$ & Konwencja zabawy & $\begin{array}{l}{[47]>\text { Cover the pictures. }} \\
\text { (uśmiech). And...the other } \\
\text { person has to guess. }\end{array}$ & $\mathrm{YF}>\mathrm{MF}$ \\
\hline $\begin{array}{l}\text { Uczestniczka opowiada jak } \\
\text { pisała mail w jęz. Angielskim } \\
\text { Lektor ma kłopoty z ustawie- } \\
\text { niem głośności }\end{array}$ & $\begin{array}{l}\text { Uznanie dla dystansu } \\
\text { do samych sie- } \\
\text { bie/dystans }\end{array}$ & $\begin{array}{l}\text { [48]I wrote an e mail to my } \\
\text { Deutch friends. } \\
>\text { Did you write in English? } \\
\text { Yes, very bad English (śmieje się) } \\
>\text { śmieje się) } \\
{[49]>\text { Can you hear anything? }} \\
\text { No } \\
\text { (śmiech) }\end{array}$ & $\begin{array}{l}\mathrm{YM}>. \mathrm{MF} \\
\mathrm{MF}>\mathrm{YM}\end{array}$ \\
\hline $\begin{array}{l}\text { Rozmowa o cechach charak- } \\
\text { teru }\end{array}$ & Ironia & $\begin{array}{l}\text { [50]I Am an optimist. } \\
>\text { Why? In his country, In his } \\
\text { weather? }\end{array}$ & $\begin{array}{l}\mathrm{YM}>\mathrm{YF} \\
\mathrm{YM}>\mathrm{YM} \\
\bullet \bullet \bullet\end{array}$ \\
\hline Rożny & Zabawne gesty & $\begin{array}{l}{[51] \text { Lektor pokazuje cos, co }} \\
\text { wywołuje uśmiech u uczestni- } \\
\text { ków }\end{array}$ & $\begin{array}{l}\text { YM, YF, MF, } \\
M M>\text { all }\end{array}$ \\
\hline $\begin{array}{l}\text { Proba podania własciwej } \\
\text { formy }\end{array}$ & $\begin{array}{l}\text { Akceptacja „kreatywno- } \\
\text { sci” }\end{array}$ & $\begin{array}{l}{[52]>\text { what's the opposite of }} \\
\text { talkative? } \\
(\ldots) \text { not talkative. } \\
>\text { not talkative. All right! } \\
\text { (śmiech). And one word? }\end{array}$ & \\
\hline $\begin{array}{l}\text { Uczestnik, który często } \\
\text { opuszcza zajęcia, rozmowa nt } \\
\text { naszych mocnych i słabych } \\
\text { stron }\end{array}$ & $\begin{array}{l}\text { Zwrócenie uwagi po- } \\
\text { przez humor }\end{array}$ & $\begin{array}{l}{[53]>\text { What are you good at? }} \\
\text { I'm NOT good at English. } \\
\text { OK, what could I do? How can I } \\
\text { help? } \\
\text { I should read more. } \\
\text { >Yes. Plus come to our classes } \\
\text { regularly. } \\
\text { Yes. } \\
\text { >Do you promise? (śmiech) }\end{array}$ & $\begin{array}{l}\mathrm{YM}>\mathrm{YM} \\
\mathrm{YF}>\mathrm{YF}\end{array}$ \\
\hline Słuchanie tekstu o śpiewaniu. & $\begin{array}{l}\text { „Obrona przed oczeki- } \\
\text { waniami”" }\end{array}$ & $\begin{array}{l}{[54] \text { (czyta) It is easier to sing high }} \\
\text { notes when making a surprised face... } \\
\text { Nie wiem czy dobrze rozumiem. } \\
\text { > High notes? Wysokie dźwięki. } \\
\text {... Don't look at me! (śmiech) } \\
\text { (jeden z uczestnikow demonstru- } \\
\text { je) }\end{array}$ & $\mathrm{YM}>\mathrm{YM}$ \\
\hline
\end{tabular}


Strategie interakcyjne lektorów, z którymi dorośli chca pracować

\begin{tabular}{|c|c|c|c|}
\hline & & $\begin{array}{l}{[55] \text { (...) I'm old. }} \\
\text { >Let us not go into this black } \\
\text { kind of humour. }\end{array}$ & MF \\
\hline $\begin{array}{l}\text { Rozmowa o przestępstwach } \\
\text { (Crime) }\end{array}$ & $\begin{array}{l}\text { Humor elicytacji } \\
\text { (pogawędka z przymru- } \\
\text { żeniem oka) }\end{array}$ & $\begin{array}{l}{[56]>\text { Have you ever done any- }} \\
\text { thing illegal? ... } \\
\text { Don't worry, everything stays in } \\
\text { this room. (smiech) }\end{array}$ & $\begin{array}{l}\mathrm{YF}>\mathrm{MF} \\
\mathrm{YM}>\mathrm{MF}\end{array}$ \\
\hline $\begin{array}{l}\text { Poprzedniego dnia - święto } \\
\text { kota }\end{array}$ & & $\begin{array}{l}{[57]>\ldots \text { you have a cat. Did you }} \\
\text { do any nice things to your cat? }\end{array}$ & $\begin{array}{l}\mathrm{MF}>\mathrm{MM} \\
\mathrm{MF} \bullet\end{array}$ \\
\hline $\begin{array}{l}\text { Ćwiczenia na mówienie } \\
\text { (crime) }\end{array}$ & $\begin{array}{l}\text { Komentarz do słów } \\
\text { uczestnika }\end{array}$ & $\begin{array}{l}\text { [58] S1: I have never killed any- } \\
\text { body. But sometimes I want. } \\
\text { (śmieje się). My husband. } \\
\text { (śmiech) } \\
\text { S2: I have never killed anybody } \\
\text { >You have an ideal husband. } \\
\text { (śmiech) } \\
\text { [59] S1:She likes cold soup. } \\
\text { > which is crazy. } \\
\text { [60]I get up at 6.22 } \\
\text { > you are very precise (uśmiech) }\end{array}$ & $\begin{array}{l}\mathrm{YF}>\mathrm{MF} \\
\mathrm{YM}>\mathrm{YM} \bullet \\
\mathrm{MF}>\mathrm{MM} \\
\mathrm{MF}\end{array}$ \\
\hline Rozmowa o zakupach & $\begin{array}{l}\text { Zabawne elementy } \\
\text { języka }\end{array}$ & $\begin{array}{l}\text { [61]>yeah, some people shop till } \\
\text { they drop. Do you know the } \\
\text { idiom? }\end{array}$ & $\begin{array}{l}\mathrm{MF}>\mathrm{MM} \text {, } \\
\mathrm{MF}\end{array}$ \\
\hline Dowolny element leksykalny & $\begin{array}{l}\text { Zabawne historyjki z } \\
\text { życia }\end{array}$ & $\begin{array}{l}\text { [62](scratch the car) } \\
\text { >this woman (śmieje się) } \\
\text { scratched her car twice into the } \\
\text { same bulding. Kr, kr, kr. Oh my } \\
\text { God! (śmiech) }\end{array}$ & $\begin{array}{l}\mathrm{MF}>\mathrm{MF} \\
\mathrm{MM} \bullet\end{array}$ \\
\hline
\end{tabular}

\section{Użyte symbole:}

YF/YM kobieta/mężczyzna w młodym wieku

MF, MM kobieta/mężczyzna w średnim wieku

.. pauza

$>\quad$ sekwencja Lektora

(...) słowa niesłyszalne

- $\quad$ powtarzanie się strategii

$><\quad$ szybkie tempo

[ nakładanie się głosu

*** imię uczestnika/czki 